\title{
COMMENTS
}

\section{WHEN LIQUIDATIONS BECOME REORGANIZATIONS: THE ELEMENT OF "CONTROL"}

$P_{\text {Resent revenue law gives the complete liquidation of a corpora- }}$ tion quite favorable tax treatment. ${ }^{1}$ If a liquidation is carefully planned, gains from sales of corporate assets during the course of the liquidation will not be taxed at the corporate level. ${ }^{2}$ Furthermore the distributions to shareholders upon liquidation are taxed as capital rather than ordinary gains. ${ }^{3}$ Such tax benefits are conferred on the unstated premise that there is a final separation of the owners of the liquidating business from the operating assets of the business. Where the separation is complete, once and for all, there is no diffculty in securing liquidation tax advantages. However, when the separation is only partial, the owners of the liquidating corporation will obtain the tax benefits of the liquidation only if they successfully avoid having the transactions classified as a "reorganization." Under the 1954 Code none of the "liquidation" tax benefits accrue to a "reorganization," the latter being viewed as merely a change in the form of doing business rather than a termination of the business. ${ }^{4}$ This comment explores the area shown by recent develop-

\footnotetext{
${ }^{2}$ See MacLean, Problems of Reincorporation and Related Proposals of the Subchapter C Advisory Group, 18 TAx L. REv. 407 (1958); Morrison, The Line Between Liquidations and Reorganizations, 41 TAXEs 785 (1963); Nicholson, Recent Developments in the Reincorporation Area, 19 TAx L. Rev. 128, 124, 127 (1964); Rice, When Is a Liquidation Not a Liquidation For Federal Income Tax Purposest, 8 STAN. L. REv. 208 (1956).

2 Under $\$ 337$, added to the Code in 1954 , a sale by a corporation of all its assets within twelve months after adopting a plan of liquidation will produce no recognizcd gain on the sale. See BrTtKer, Federal Income Taxation of Corporations and SHAREHOLDERS 282-83 (1959).

${ }^{3}$ INT. Rev. CODE of 1954, § 331; BrTtker, op. cit. supra note 2, at 255. See generally Bittker, Taxation of Complete Liquidation, 8 TUL. TAx INST. 610 (1959); Garver, Tax Problems in Corporate Liquidations: Liquidations Under Sec. 337, 13 W. REs. L. REv. 236 (1961); Rettig, Tax Consequences of Complete Corporate Liquidations: Reincorporation Hazards, $19 \mathrm{~J}$. TAXATION 130 (1963).

- See Morrison, supra note 1, at 785-86; Rettig, supra note 3, at 130; Rice, supra note 1 , at 208-09. This has come to be known as the "liquidation-rcincorporation" problem. While the phrase "liquidation-reincorporation" aptly describes the most common instance where the reorganization provisions may upset otherwise effective liquidation tax plans, it is to a large extent a misnomer since a number of transactions classified as reorganizations have no connection with reincorporation. In practice the
} 
ments to be the most crucial and pivotal in the classification of liquidations as reorganizations-the stock control which shareholders of the liquidating corporation have over the ultimate corporate purchaser of the distributed assets. ${ }^{5}$

\section{The 1954 Code: Liquidations AND Reorganizations}

The taxation of corporate liquidations and reorganizations necessarily has dual aspects. A tax may be imposed on the corporation on gain from the sale of its assets, and the shareholders may be required to pay a tax on property they receive.

\section{A. Taxation of Liquidations}

The approach to taxability of sales of corporate assets incident to a liquidation has been substantially revised by the 1954 Code. $^{6}$ Prior to 1954, if the corporation sold the assets, gain clearly was taxed. The case law was confused as to the effect of a corporation's distribution of assets in kind which were then sold by the shareholders. The courts sometimes imputed the sale to the corporation and taxed any profit as corporate income. Other times they treated the sale as one by the shareholders, hence no corporate tax was

phrase "liquidation-reincorporation" is used to describe three basic types of transactions: (a) a liquidation of a corporation with distribution of its assets to shareholders or their nominees followed by incorporation of a new corporation identical in most respects to the old; (b) the formation of a new corporation owned by substantially the same shareholders as an existing corporation, with the older corporation then selling its assets to the new corporation and liquidating; (c) liquidation of an existing corporation and distribution of its assets to its shareholders who in turn sell, lease, or otherwise put these assets at the disposal of a new corporation formed at some time prior to the liquidation, the shareholders receiving stock in the acquiring corporation in the exchange.

Many possible variations of these basic transactions can be hypothesized: the use at some stage of dormant corporations, personal holding companies, or trustees, for example. See Nicholson, supra note I, at 123-24; Rice, supra note 1, at 209.

- See Holzaran, Corporate Reorganizations \$3:19 (2d ed. 1955); Goldman, Revised "Reincorporation Doctrine" Upsets Planners: Rev. Rul. 61-156 Analyzed, $17 \mathrm{~J}$. TAXATion 148, 149-50 (1964); Mayer, Ramifications of the Treasury's LiquidationReincorporation Doctrine, 25 U. PITT. L. REv. 637, 647 (1964); Pennell, Developments and Unanswered Questions in Corporation Reorganizations, 42 TAxes 889 (1964).

- Prior to the 1954 Code the Treasury in its regulations provided for nonrecognition of gain on distributions of appreciated property to shareholders in a complete liquidation. However, where the corporation first sold the assets and then distributed the proceeds a gain was recognized. See McGaffey, The Rationale and Requirements of Section 337, 40 TAXES 681, 683 (1962). The early Treasury Regulations were codified in 1954 in $\$ 336$, which provides for nonrecognition of gain or loss on property distributed in "complete or partial liquidation." (Emphasis added.) 
payable. $^{7}$ Under a new section of the 1954 Code, section $337,{ }^{8}$ all sales by a corporation of its assets incident to a "complete" liquidation were made tax free if the distributions to shareholders were completed within twelve months after adoption of a plan of liquidation. $^{\circ}$ A carefully planned and executed liquidation is therefore untaxed at the corporate level.

The more important aspect of liquidation tax treatment is the manner in which the 1954 Code treats liquidating distributions in the hands of shareholders. As a general rule distributions from a corporation to its shareholders are taxed as dividends under section 301.10 However, when a corporation undergoes a complete liquidation, section $331^{11}$ provides that the liquidating distribution is not considered a dividend but rather a sale or exchange of stock by the shareholder. The result is taxation at capital gains, rather than ordinary, rates. ${ }^{12}$

Capital gains treatment is not the only favorable tax consequence which may flow from a complete liquidation. Under section 334 (a)

${ }^{7}$ See Commissioner v. Court Holding Co., 324 U.S. 331 (1943), Note, 63 Harv. L. REv. 484 (1950), which imputed a sale by shareholders following liquidation to the corporation which was required to report the gain on the sale as corporate income. But see United States v. Cumberland Pub. Serv. Co., 338 U.S. 481 (1950).

${ }^{8}$ INT. REv. CODE OF 1954, \$337.

"(a) GENERAL Rule. If and

(1) a corporation adopts a plan of complete liquidation on or after Junc 22, 1954,

(2) within the 12-month period beginning on the date of the adoption of such plan, all of the assets of the corporation are distributed in complete liquidation, less assets retained to meet claims, then no gain or loss shall be recognized to such corporation from the sale or exchange by it of property within such 12-month period."

- The objective of the 1954 change in $\$ 337$ was once and for all to "divorce the tax consequences of the liquidation-sale combination from the form of the transaction." BITTKER, op. cit. supra note 2, at 290.

${ }^{10}$ INT. REV. CODE OF 1954, §30I (c) (1).

"That portion of the distribution which is a dividend ... shall be included in gross income."

${ }^{11}$ INT. Rev. CODE of 1954, §331.

“(a) General Rule.

(1) Complete Liquidations. Amounts distributed in complete liquidation of a corporation shall be treated as in full payment in exchauge for the stock."

12 Capital gains treatment has been justified on the theory that the situation is not different from the sale of stock and that the treatment should therefore be not different from that given the proceeds of stock sales. See S. REP. No. 398, 68th Cong., 1st Sess. pt. 1, at 11-12 (1924), reprinted in 1939-1 Cum. BuL.. pt. 2, at 274. There is a significant difference, however, between a sale of stock by a shareholder and redemption of stock in a liquidation, since in the latter instance there is no replacement of shareholders which would leave corporate earnings intact. BITTKER, op. cit. supra note 2, at 255-56; cf. SURREY \& WARREN, FEDERAL INCOME TAXATION 1264 (1960 ed.); Rice, supra note 1 , at 210-11. 
it is provided that the basis of property received in a complete liquidation is its fair market value on distribution. ${ }^{13}$ Thus if a liquidating corporation owns property which it has greatly depreciated and which has a market value above its adjusted basis, the sale of these assets in a transaction contemplating complete liquidation will entitle the purchaser to a step-up in basis. ${ }^{14}$

This favorable liquidation treatment has led to various schemes whereby a corporation is first liquidated and then reincorporated in an effort to step-up the basis of the corporate assets at the relatively cheap cost of a capital gains tax..$^{15}$ Quite clearly this is an abuse of the liquidation tax preference. ${ }^{16}$ A second type of abuse has developed where a corporation has accumulated sizeable amounts of undistributed earnings that it wishes to withdraw from the corporation at a capital gains rate, yet without terminating the business. ${ }^{17}$ A straightforward distribution in the form of a cash payment to stockholders would obviously result in a tax at ordinary dividend rates. ${ }^{18}$ But if the assets of the corporation are distributed to the shareholders in a "complete liquidation" and the operating assets are then "reincorporated" in a new corporation there is a possibility of having to pay only a capital gains tax on this distribution. ${ }^{19}$

\section{B. Taxation as a Reorganization to Miligate Abuses of Liquidation Preference}

These abuses of the liquidation tax preference by de facto continuation of the underlying business in a new corporate form pre-

\footnotetext{
${ }^{18}$ INT. REv. Code of 1954, \$394 (a); see generally BrTtKer, op. cit. supra note 2, at 255-57, 258-60, 262.63.

14 BITKKE, op. cit. supra note 2, at 259, 262-63, 266; Levin, The Case for a Stepped$U p$ Basis to the Transferee in Certain Reorganizations, 17 TAX L. REv. 511-12 (1962); Teschner \& Sorden, Stepped-Up Basis on Assets Transferred to Newly Formed Corporation?, $5 \mathrm{~J}$. TAXATION 32 (1956).

15 Cf. James Armour, Inc., 43 T.C. 295 (1964).

10 See Rice, supra note 1, at 209.

${ }^{17}$ See, e.g., James Armour, Inc., 43 T.C. 295 (1964); David T. Grubbs, 39 T.C. 42 (1962); James C. Gallagher, 39 T.C. 144 (1962); see Nicholson, supra note 1, at 123; see generally Bittker, supra note 3, at 610; Kuhn, Liquidation and Reincorporation Under the 1954 Code, 51 GEo. L.J. 96 (1962); Morrison, supra note 1, at 785.

${ }^{28}$ INT. REv. CODE OF 1954, \$301; see note 10 supra and accompanying text.

${ }^{10}$ Were the transaction carried out this openly with the liquidation followed immediately by reincorporation, the plan would in all probability fail, being taxed either as a "sham" transaction, see note 79 infra, or as a two-step reorganization under $\$ 368$ (a) (1) (F), see note 45 infra and accompanying text.

To the extent the assets were not reincorporated they would be treated as taxable distributions either under $\$ 301$ or under $\$ \S 354$ and 356 . See note 37 infra; Treas. Regs. §§I.331-1 (c), 1.301-1 (l) (1955); BrTTKER, op. cit. supra note 2, at 262-63.
} 
sented difficulties long before the 1954 Code. Previously, the Commissioner had dealt with this liquidation-reincorporation problem under the predecessor of current section 368 (a) (I) (D), ${ }^{20}$ which provided for the nonrecognition of gain where a corporation transferred all or a part of its assets to another corporation controlled by the transferor or its stockholders immediately after the transfer. ${ }^{21}$ Under this provision and also by use of the "step transaction" theory 22 the Commissioner found little difficulty in getting the courts to tax reincorporation after liquidation as a reorganization where stockholders of the liquidated transferor corporation "controlled" the transferee immediately after the transfer. ${ }^{23}$ But his successes were

${ }^{20}$ INT. REv. CODE OF 1939, \$112g(1).

${ }^{21}$ INT. REv. CODE OF 1939, $\$ 112 \mathrm{~g}$ (I) provides:

"(1) the term 'reorganization' means ... (D) a transfer by a corporation of all or a part of its assets to another corporation of all or a part of its assets to another corporation if immediately after the transfer the transferor or its shareholders or both are in control of the corporation to which the assets are transferred ...."

22 The "Step Transaction" theory like the "Business Purpose" doctrine, see note 45 infra and accompanying text, and the "Continuity of Intercst" doctrine, see note 46 infra and accompanying text, is an interpretative judicial tool used to determine tlic true substantive nature of a business transaction for tax purposes. The essence of the step transaction is that intermediate steps in a series of corporate actions will be ignored where they lack independent business significance. Wcyl-Zuckerman \& Co., 23 T.C. 841 (1955), aff'd per curiam, 232 F.2d 214 (9th Cir. 1956). The emphasis of the step transaction doctrine is on the end result, omitting from judicial cognizance intervening actions. "When we must determine whether there has been a reorganization, a sale, or an exchange in a series of transactions, it is proper for us to look at the beginning and end of the series." William M. Liddon, 22 T.C. 1220, 1225 (1954). Sometimes the step transaction is used to produce a reorganization, David T. Grubbs, 39 T.C. 42 (1962), and sometimes to defeat a claimed reorganization, Helvering v. Elkhorn Coal Co., 95 F.2d 732 (4th Cir. 1937); cf. Helvering v. Alabama Asphaltic Limestone Co., 315 U.S. 179, 184 (1941). See generally Paul \& Zimct, Step Transactions, in Selected Studies in Federal Taxation 200-54 (2d Ser. 1938); Manning, "In Pursuance of the Plan of Reorganization": The Scope of the Reorganization Provisions of the Internal Revenue Code, 72 Harv. L. REv. 881, 900 (1959); Mintz \& Plumb, Step Transactions in Corporate Reorganizations, 12 N.Y.U. 12TH INST. ON FED. TAX 247 (1954); Comment, 42 N.C.L. REv. 373, 377 n.17, 386-87 (1964).

2s Under the 1939 Code the courts, with emphasis on the "Business Purpose" doctrine, see note 45 infra, and the "Step Transaction," see note 22 supra, strucl: down several attempts to gain a tax advantage through liquidation-reincorporation where control of the reincorporated corporation had not changed. In Bard-Parker Co. v. Commissioner, 218 F.2d 52 (2d Cir. 1954), the second circuit prevented a step-up in basis. A net operating loss carry-back was frustrated in Pebble Springs Distilling Co., 23 T.C. 196 (1954). And an attempt to secure a loss advantage where market value was less than basis was prevented in Survaunt v. Commissioner, 162 F.2d 753 (8th Cir. 1947). The emphasis of these courts was on the continuation of the underlying business under substantially similar ownership with the only change being in the form of intervening transactions. Lewis v. Commissioner, 176 F.2d 646 (Ist Cir. 1949), affirming 10 T.C. 1080 (1948); cf. Bazley v. Commissioner, 331 U.S. 737 (1947), rehearing denied and earlier opinion amended, 332 U.S. 752 (1947).

There were some cases, however, which recognized that liquidation followed by 
limited to cases where the steps leading to the reincorporation were so direct as to indicate contemplation of the final result at the time of liquidation, ${ }^{24}$ and to cases where shareholders of the transferor held more than an eighty per cent interest in the transferee. ${ }^{25}$

Because of the difficulties faced by the Commissioner in correcting abuses by invoking the reorganization provisions, the revisers of the 1954 Code sought a legislative solution. ${ }^{26}$ They proposed the addition of a new section ${ }^{27}$ which would provide for nonrecognition of gain or loss on the sale of assets by a corporation whose shareholders "controlled" the purchasing corporation, with control being defined as the ownership of fifty per cent of the voting stock of the purchaser. ${ }^{28}$ Under the proposed section the purchaser acquired the seller's basis in the assets, hence preventing any step-up. ${ }^{29}$ This

continuation of the corporation should not always be denied effectiveness, as where old shareholders had no continuing interest, Fowler Hosiery Co., 36 T.C. 201 (1961), aff'd, 301 F.2d 394 (7th Cir. 1962), or where although there was a transfer to another corporation in which old shareholders had an interest, the old corporation's business was not continued. Hellmich v. Hellman, 276 U.S. 233 (1928).

The trend of the decisions under the 1939 Code met with additional dissents. In United States v. Arcade Co., 203 F.2d 230 (6th Cir. 1953), the Sixth Circuit held that there was no reorganization because the shareholders of the old corporation had not bound themselves to carry out any plan of reorganization. Also where the $80 \%$ control test of $\S 112(\mathrm{~g})$, see note 20 supra and accompanying text, was not met, the Tax Court in Austin Transit, Inc., 20 T.C. 849 (1953) allowed a step-up in basis, finding no reorganization in the statutory sense. Where the separate transactions came nine months apart the Tax Court in Charles R. Mathis, Jr., 19 T.C. 1123 (1953), held that a single plan of reorganization was absent and thus a factor necessary to activate the reorganization sections of the Code was missing. See Morrison, The Line Between Liquidations and Reorganizations, 41 TAXEs 785, $791-92$ (1963). For considerably more detailed discussion of the authorities under the 1939 Code, see MacLean, supra note 1, at 408-13, 417-18; Rice, supra note 1, at 211-16.

24 E.g., Charles R. Mathis, 19 T.C. 1123 (1953). There, it was established that the reincorporation was not contemplated at the time of liquidation. The Tax Court allowed the shareliolder-taxpayer to avoid classification as a $D$ reorganization.

${ }^{25}$ See Austin Transit, Inc., 20 T.C. 849 (1953), involving a sale of assets from a liquidating corporation to a corporation owned in part by shareholders of the liquidating company. The shareholders owned $45 \%$ of the transferee's stock, and the Tax Court refused to accord the transaction $D$ reorganization treatment. See also Morrison, supra note 1, at 791; Rice, supra note 1 , at 220.

28 See H.R. Conf. ReP. No. 2543, 83d Cong., 2d Sess. 41 (1954), which accompanied H.R. 8300, 83d Cong., 2d Sess. 41 (1954). "Your committee's bill . . . also contains a specific provision designed to make impossible the withdrawal of corporate earnings at capital gains rates through the device of liquidating the corporation and reincorporating the business assets, a device which has been sanctioned by certain courts under existing law." H.R. 8300, 83d Cong., 2d Sess. 40 (1954).

${ }^{37}$ See MacLean, supra note 1, at 407; Morrison, supra note 1, at 786; Rice, supra note 1, at 223-24; see also 2 ALI FED. Income TAX STAT. \$ X522 (Feb. 1954 Draft).

${ }_{28}$ Compare INT. REv. CoDe of 1954, $\$ 368$ (c), which set the "control" requirement at $80 \%$ of voting stock and of the total number of all non-voting shares.

so Compare note 14 supra and accompanying text. 
section could have been most useful in correcting the abuses of the liquidation preference, but it was eliminated in the final draft of the $\operatorname{Code}^{30}$ with the comment that any possibility of tax avoidance by reincorporating a liquidated corporation could "appropriately be disposed of by judicial decision or by regulation within the framework of other provisions of the bill."31 The only "other" provisions of the Code that could be adapted to preventing abuses of the liquidation benefits were the reorganization sections, ${ }^{32}$ which

${ }^{30}$ H.R. CoNF. REP. No. 2543, 83 Cong., 2d Sess. 41 (1954). The proposed section, 357, would have applied in any case where $50 \%$ or more of the operating assets of the liquidated corporation were reincorporated by $50 \%$ or more of the shareholders of the liquidated corporation within five years after liquidation was complete. In the event of reincorporation, the liquidating distribution was to be taxed as a dividend to the extent of accumulated earnings and profits unless it could be shown that tax avoidance was not a principal purpose of the transaction. BNA, TAx Management, MEmo. 64-22, at 3 (1964).

31 H.R. CONF. REP. No. 2543, 83d Cong., 2d Sess. 41 (1954). "This provision gave rise to certain technical problems . . . . [Further, . . . the possibility of tax avoidance in this arca is not sufficiently serious to require a special statutory provision." Ibid.

An attempt was made in 1959 to resolve the reincorporation problem legislatively. See H.R. 4459, 86th Cong., Ist Sess. (1959), reprinted in Hearings Before the House Committee on Ways and Means on Advisory Group Recommendations on SubChapters, $C, J$, and $K$ of the Internal Revenue Code, 86th Cong., 1st Sess. 556, 596-97 (1959) [hereinafter cited as 1959 Hearings]. Sec also MacLean, supra note 1, at 407.

The recommended legislation specifically made a liquidation-reincorporation transaction applicable where shareholders of the transferor corporation owned $50 \%$ of the transferee's stock, as opposed to the current $80 \%$ figure. Proposed Amendment $\S 368$ (a) (1) (D) and $\$ 368$ (c), 1959 Hearings 596-97. As a complement to this amendment, $\S 337$ was limited so as not to apply to sales or exchanges to which $C, D$, or $F$ reorganization provisions applied. Proposed Amendment \$337(c) (1), 1959 Hearings 596. See also MacLean, supra note 1, at 430-31.

While this proposal was not without its diffculties, it would have dealt with the bulk of the liquidation-reincorporation avoidance schemes. It was not adopted, however, and the Commissioner was forced to attempt a satisfactory solution in the courts. Lane, The Reincorporation Game: Have the Ground Rules Really Changed?, 77 HARv. L. REv. 1228, 1243 (1964). See generally Schwartz, Reincorporations Under the 1954 Code, 15 U. FLA. L. REv. 159 (1962).

${ }^{32}$ The heart of the reorganization sections, $\$ \S 351-68$, is $\S 361$ (a), which provides that "no gain or loss shall be recognized if a corporation a party to a reorganization exchanges property, in pursuance of the plan of reorganization, solely for stock or securities in another corporation a party to the reorganization." INT. REv. CODE OF $1954, \S 361$ (a). This gives nonrecoguition treatment to all of the reorganizations defined in $\$ 368$ except $\$ 368$ (a) (1) (D), which deals with asset transfers by a corporation to another corporation controlled by its sharcholders. However, $\$ 361$ (b) (1) allows nonrecognition for these $\S 368$ (a) (1) (D) transactions so long as all money and other property other than stock or securities is distributed to shareholders pursuant to a plan of reorganization.

The basis of property involved in a reorganization is delineated in $\S 362$, which provides that the basis of property transferred in a reorganization "shall be the same as it would be in the hands of the transferor, increased in the amount of gain recognized to the transferor on such transfer." INT. REv. CoDE OF 1954, §362 (b). 
the Commissioner had been using for this purpose even before the 1954 revision. ${ }^{33}$

The Commissioner's most useful reorganization section is 368 (a) (I) (D), commonly denoted as a "D reorganization." In general terms, it classifies as a reorganization transfers of assets by one corporation to another, the latter being controlled by one or more of the transferor's shareholders. ${ }^{34}$ Unfortunately instead of strengthening the Commissioner's position with respect to $D$ reorganizations, the new Code made it even more difficult $t^{35}$ by adding new requirements. ${ }^{36}$ Under the amended act, before a transaction qualified as a $D$ reorganization "the stock or securities of the corporation acquiring the assets must be distributed by the transferor of the assets to its shareholders" in a transaction which meets the requirements of either sections 354,355 or $356 . .^{37}$ Thus, the types of stock distributions which will suffice to confer $D$ reorganization status on the transaction are the following: (1) Under section 354, the old corporation transfers "substantially all" of its assets to the new, receives stock of the new corporation in exchange for these assets, and then redeems all of its own stock or securities in exchange for the newly acquired stock; ${ }^{38}$ (2) Under section 355, an existing corporation dis-

\footnotetext{
${ }^{33}$ See text accompanying notes 20-25 supra.

s4 INT. REv. CODE of $1954 \S 368$ (a) (1) (D). For the full statutory text, see note 36 infra.

sc See Mayer, Ramifications of the Treasury's Liquidation-Reincorporation Doctrine, 25 U. PITT. L. REv. 637, 639 (1964); Nicholson, supra note 1, at 127. See generally, Grubb, Corporate Manipulation Under Subchapter C, Reincorporation-Liquidation, 28 U. Cinc. L. REv. 304 (1959).

36 "Reorganization" means: “(D) a transfer by a corporation of all or part of its assets to another corporation if immediately after the transfer the transferor, or one or more of its shareholders (including persons who were shareholders immediately before the transfer), or any combination thereof ITS SHAREHOLDERS OR BOTH is in control of the corporation to which the assets are transferred; OR but only if in pursuance of the plan, stock or securities of the corporation to which the assets are transferred are distributed in a transaction which qualified under section 354,355 or 356 .... INT. REv. CODE of 1954, §368(a) (1) (D). The italicized material was added in 1954, and the capitalized material was deleted.

37 2 Mertens, LAw OF FEDERAL InCOME TAXation $\$ 20.91$, at 410 (rev. ed. 1961).

38 "(b) EXCEPTION.-

(1) IN GENERAL. -Subsection (a) (providing non-recognition) shall not apply to any exchange in pursuance of a plan of reorganization within the meaning of section 368 (a) (1) (D), unless- (A) the corporation to which the assets are transferred acquires substantially all of the assets of the transferor of such assets; and (B) the stock, securities, and other properties received by such transferor, as well as the other properties of such transferor, are distributed in pursuance of the plan of reorganization." InT. REv. CODE of 1954, §354 (b) (l) (A) and (B). (Emphasis added.)
} 
tributes to its shareholders or security holders enough stock to divest itself of control of a corporation of which for five years it had held eighty per cent control;39 (3) Under section 356, a stock exchange may qualify under sections 354 or 355 although boot accompanies the transfer. ${ }^{40}$

\section{A Dulemma in Gurbing Tax Avoidance Under the Reorganization Sections of the 1954 Code}

Under the 1954 Code, the reorganization sections have, as their primary function, the nonrecognition of gain when changes are made in a corporation which do not significantly alter the basic nature of the relationship between the owner and the enterprise so as to justify taxation of gain resulting from a corporate adjustment. ${ }^{\mathbf{} 1}$ Reorganization provisions are applicable where corporations merge or consolidate, ${ }^{42}$ where the stock or assets of the corporation are acquired by another, or where the corporation is recapitalized or merely changes its form.43 Where such changes are for business purposes $^{44}$ and are accompanied by a sufficient continuity of share-

${ }^{39}$ INT. Rev. CODE of 1954, \$355. Cf. Cordes, Device of Divisive Reorganization, 10 KAN. L. REv. 21 (1961); Pennell, Divisive Reorganization and Corporate Contractions, 33 TAXES 924 (1955).

${ }^{10}$ INT. REv. CODE OF 1954, §356. The term "boot" refers to all property in cash or kind other than stock and kindred securities. It is derived from the cliche "to boot," as in "this property and that to boot." William M. Liddon, 22 T.C. 1220, 1226 (1954).

11 Kuhn, Liquidation and Reincorporation Under the 1954 Code, 51 GEo. L.J. 96, 107 (1962); Maclean, supra note 1, at 413-17; Rice, supra note 1, at 225-26.

42 Treas. Reg. $\$ 1.368-1$ (b) (1955); BITTKER, op. cit. supra note 2, at 358.

43 INT. REv. CoDE of $1954, \$ 368$ (a) (1) (A) provides that a reorganization encompasses " (A) a statutory merger or consolidation ...."

"INT. REv. CODE OF 1954, $\$ 368$ (a) (1) provides that the following shall be considered reorganizations:

“(B) the acquisition by one corporation, in exchange solely for all or a part of its voting stock (or in exchange solely for all or a part of the voting stock of a corporation which is in control of the acquiring corporation), of stock of another corporation if, immediately after the acquisition, the acquiring corporation has control of such other corporation (whether or not such acquiring corporation had control immediately before acquisition);

"(C) the acquisition by one corporation, in exchange solely for all or a part of its voting stock (or in exchange solely for all or a part of the voting stock of a corporation which is in control of the acquiring corporation), of substantially all of the properties of another corporation but in determining whether the exchange is solely for stock the assumption by the acquiring corporation of a liability of the other, or the fact that property acquired is subject to a liability, shall be disregarded;"

$\ldots$...

"(E) a recapitalization; or

"(F) a mere change in identity, form, or place of organization, however effected." 
holder interest, ${ }^{45}$ the adjustment is tax-free and there is a carryover of asset basis ${ }^{46}$ and other tax incidents ${ }^{47}$ from the old to the new corporation.

While the reorganization sections serve as permissive methods of making corporate alterations, they also prevent tax avoidance. ${ }^{48}$ It is especially important to preclude two tax-avoidance plans in effectuating this preventive purpose. The first of these schemes is the attempt to disguise a sale as a reorganization so as to avoid present taxation. ${ }^{49}$ The second is the attempt to disguise a reorganization as a liquidation so as to minimize tax treatment for distributed property and to achieve a step-up basis for transferred assets. ${ }^{50}$

"The "Business Purpose" test was developed in Gregory v. Helvering, 293 U.S. 465 (1935), under circumstances where the taxpayers were seeking to gain rather than avoid reorganization treatment. The Gregory decision made it clear that mere compliance with the language of the statutory provisions was not enough, that there must be in addition a business purpose for a reorganization. In this regard the decision was merely a reiteration of the doctrine of disregarding "sham" transactions. See Michaelson, "Business Purpose" and Tax Free Reorganization, 61 YAlE L.J. 14 (1952); Rice, Judicial Techniques in Combating Tax Avoidance, 51 MrcH. L. REv. 1021 (1953); cf. Treas. Reg. $\$ 1.368-1$ (b) (1955).

10 The "Continuity of Interest" doctrine is analogous to the "Business Purpose" doctrine, see note 45 supra, in that it antedates the 1954 Internal Revenue Code and was concerned more with those who were seeking rather than those who were avoiding reorganization status. As its name implies the doctrine requires that there be a continuing equity interest on the part of the shareholders of the corporation being reorganized. Cf. Brookes, The Continuity of Interest Test in Reorganizations-Blessing or Curse, 34 CALIF. L. REv. 1 (1946). Under the 1954 Code the Judicial requirement of "continuity of interest" has been articulated in the statute, both in the voting stock requirements of $\S 368(a)(1)(B)$ and $(C)$ and by the control requirements of $\S 368$ (c) as incorporated in $\$ 368$ (a) (1) (D). But see Treas. Reg. $\S 1.368-2$ (g) (1955). See generally BITTKER, op. cit. supra note 2, at 357-63; Baker, Continuity of Interest Requirement in Reorganizations Reexamined-the Hickok Case, 18 N.Y.U. 20TH INST. ON FED. TAX 761 (1960); Tarleau, "Continuity of the Business Enterprise" in Corporate Reorganizations and Other Corporate Readjustments, 60 CoLuM. L. REv. 792 (1960).

"INT. Rev. CODE OF 1954, \$362.

${ }^{4}$ See $\$ 381$, enacted in the 1954 Code, which provides for the carryover to the transferee corporation of the transferor's net operating losses carryover, earnings and profits, and other tax attributes such as accounting methods and computation of depeciation. But see $\$ 382$ (b) which provides certain enumerated limitations. See generally the materials in S. REP. No. 1622, 83d Cong., 2d Sess. 52, 277 (1954); Fager, Reorganizations: Recapitalizations, Tax-Free Acquisitions, 15 N.Y.U. 15TH INST. ON FED. TAX 413 (1957).

"See notes 20-25 supra and accompanying text.

${ }^{50}$ The initial reorganization sections of the Internal Revenue Code were introduced in the 1921 Internal Revenue Act. See generally SeIdman, Legrsiative History of Federal Income TaX Laws 1938-1861, at 341-42 (1938). See also H.R. ReP. No. 486, 67th Cong., 1st Sess. (1921); H.R. Rep. No. 350, 67th Cong., 1st Sess. (1921); S. Rep. No. 275, 67th Cong., 1st Sess. (1921). The major problem under the 1921 law proved to be "the adroitness of attorneys in planning sales in such a way as to come within the scope of the reorganization provisions." "SErdman, supra at 340 . While it was 
These two tax avoidance problems pose a dilemma for effective utilization of the reorganization provisions to combat both schemes. Both sales seeking to masquerade as reorganizations and reorganizations seeking favorable treatment as liquidations are treated by the 1954 Code under the same control requirement. ${ }^{51}$ The impact of the reorganization sections in thwarting tax avoidance is largely a co-variant of the amount of shareholder control which necessitates reorganization treatment. Variance of the control requirements poses the dilemma in clearest focus. If a low percentage of continuing control in the transferee corporation results in a reorganization, this affords an opportunity for tax avoidance by disguising a "sale" as a reorganization. ${ }^{52}$ This scheme is virtually eliminated by requiring that shareholders of the selling corporation have a high percentage control in the purchasing corporation. ${ }^{83}$ However, if a reorganization results only when there is a high percentage of control, an opportunity for tax avoidance is afforded in cases where a mere change in the corporate form is made for the sole purpose of qualifying for liquidation benefits. ${ }^{54}$ The smaller the percentage control required, the less likely is the possibility that there will be avoidance by this method, since a larger and larger amount of "actual" control over the corporation will have to be given up to

proposed in 1933 that the entire exchange and reorganization provisions of the Code, then $\$ 112$, be abolished in order to preclude the prevalent methods of tax avoidance, this proposal was rejected in favor of amending the provisions. H.R. REP. No. 704, $73 d$ Cong., 2d Sess. 12-14 (1934). The $80 \%$ control figures set by the proposed amendment were clearly aimed at preventing further abuse by disguised sales. "By these limitations the committee believes that it has removed the danger that taxable sales can be cast into the form of a reorganization ...." H.R. REP. No. 704, 73d Cong., 2d Sess. 14 (1934). This amendment is presently embodied in INT. REv. CoDE of 1954, $\S 368$.

${ }^{51}$ See Mayer, supra note 35 , at 638 .

52 See note 73 infra. The $80 \%$ requirement of $\$ 368$ (c) was first introduced into the Internal Revenue Code in the 1921 Act. 42 Stat. 227, 230 (1921). Minor changes were made in the 1936 Act intending to assure that "voting stock" meant number of votes, not number of shares. See SEIDMAN, op. cit. supra note 50, at 243.

¿3ee note 50 supra.

st For example, suppose corporation $A$ has a large amount of undistributed earnings and profits which it wishes to withdraw. One plan is to distribute the operating assets and retained earnings and profits to its shareliolders and then reincorporate the operating assets. If the control requirement for reorganization treatment is $80 \%$, then, so long as the shareholdings of the new corporation include more than a $20 \%$ holding by persons not originally shareholders of corporation $A$, the reorganization provisions which provide for nonrecognition of the gain would not apply and the distribution to stockholders would be treated as a liquidating payment in exchange for stock under $\$ 331$, hence qualifying for capital gains rather than dividend treatment. 
escape treatment of the transaction as a reorganization. ${ }^{55}$ Thus, a high percentage of control is necessary to curb the sale-reorganization abuses, while a low percentage is requisite to prevent misuse of liquidation provisions.

When control requirements were first introduced into the reorganization sections of the Code in the Revenue Act of $1921^{56}$ Congress was primarily concerned with the sale-reorganization problems ${ }^{57}$ of the reorganization provisions..$^{58}$ The result is that while the reorganization sections are presently well adapted to carrying out their function of postponing a tax until a gain is realized from a pure sale, the high percentage requirement limits their usefulness as deterrents of tax avoidance by liquidation-reincorporation. This result obtains because the reorganization sections can be avoided by giving up control of more than twenty per cent of a corporation organized to carry on the old corporate business, ${ }^{59}$ as the current provisions call for a retention of eighty per cent control before reorganization treatment is imposed.

\section{Developments Implementing The Code}

\section{Regulations}

With the 1954 Code amendments further limiting the effectiveness of the $D$ reorganization, the Commissioner sought to devise new approaches to combat the liquidation-reincorporation problem..$^{60}$ Immediately after the adoption of the new Code, two new treasury regulations were announced. 1 The first of these was Regulation $1.331,62$ which attacked the reincorporation problem by limiting the consequences of complete liquidation to only those cases where a

\footnotetext{
es But see Berle \& Means, The Modern Corporation and Private Property 69 (1932).

¿6 42 Stat. 230 (1921).

ot See SeIdMan, op. cit. supra note 50 , at $\mathbf{8 4 0}$.

is In fact, when the present control requirement of $80 \%$ was adopted in the 1921 act, $\S 331$ and its attendant problem of avoidance was not yet part of the Code and obviously could not have been taken into account when the percentage control requirement was fixed. Section 381 of the present Code was first made a part of the Internal Revenue Code in the Internal Revenue Act of 1936, 49 Stat. 1648 (1986). ${ }^{\circ}$ See generally MacLean, Problems of Reincorporation and Related Problems of the Subchapter C Advisory Group, 13 TAx L. Rev. 407, 416 (1958).

${ }^{\circ}$ See text accompanying note 35 supra.

${ }^{01}$ Treas. Reg. $\$ 1.331$ (1955) and Treas. Reg. $\$ 1.301$ (c) (1955).

02 Treas. Reg. $\$ 1.331$ (1955).
} 
real liquidation had taken place. ${ }^{63}$ Emphasizing that all steps in a transaction must be taken into account in determining whether a complete liquidation under section 331 had in fact taken place, the Commissioner sought to deny the benefits of complete liquidation to those who, following a purportedly complete liquidation, continued the operating business in a new corporate shell with substantially the same ownership but under circumstances not meeting the restrictive prerequisites of a $D$ reorganization. ${ }^{64}$ The second of the pair of new regulations was issued under section 301 and took a different tack. It treated distribution made in connection with a liquidation as potentially two transactions. ${ }^{65}$ Where both stock and other property are distributed at the same time and take the form of a liquidation, the Commissioner will look to the substance of the transaction and treat part of the property distribution as a dividend and part as a liquidation if the two are in substance, though not in form, separate transactions. To the extent that such a distribution represents accumulated earnings and profits, the Commissioner purported to accord it dividend status. ${ }^{66}$

These new regulations were intended to accomplish two purposes with respect to the liquidation-reincorporation problem. The first was an effort to avoid reliance on a $D$ reorganization and its attendant technical restrictions. ${ }^{67}$ The second purpose was to avoid the tax treatment accorded by section 356 to a distribution made in connection with a reorganization. ${ }^{68}$ Section 356 provides that where

o2 "A liquidation which is followed by a transfer to another corporation of all or part of the assets of the liquidating corporation or which is preceded by such a transfer may, however, have the effect of the distribution of a dividend or of a transaction in which no loss is recognized and gain is recognized only to the extent of 'other property." " Treas. Reg. \$1.331-1 (c) (1955).

* Morrison, The Line Between Liquidations and Reorganizations, 41 Taxes 785 (1963).

${ }^{\circ 6}$ Cf. note 22 supra.

Bs "Transactions treated as distributions. A distribution to shareholders with respect to their stock is within the terms of section 301 although it takes place at the same time as another transaction if the distribution is in substance a separate transaction whether or not connected in a formal sense. This is most likely to occur in the case of a recapitalization, a reincorporation, or a merger of a corporation with a newly organized corporation having substantially no property ...." Treas. Reg. $\$ 1.301-1(l)$ (1955). (Emphasis added.)

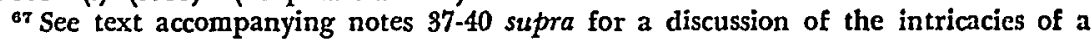
$D$ reorganization.

88 "These regulations are in part directed against the provisions of $\$ 356$, which limit dividend treatment on 'boot' received in a reorganizaton to the amount of gain realized on the exchange." Some commentators feel that $\S 301$ dividend treatment rather than $\$ 356$ boot treatment should be given distributions to shareholders in a 
cash or other "boot" is distributed in addition to stock, the shareholder recipients are taxable only to the extent of the gain realized on the exchange. ${ }^{69}$ However, it is the Commissioner's position, as reflected in both of the above regulations, that the shareholder should be taxed to the extent of undistributed earnings and profits which he receives and not merely on his gain. ${ }^{70}$ Thus, suppose that a shareholder's common stock were exchanged for stock and bonds in a reincorporated company and had a combined value equal to the shareholder's basis in the old common stock. Where the bonds represent undistributed earnings of the corporation, under the above regulations their distribution would be considered a "separate transaction" and would be treated as ordinary dividend income under section 301.71 Were the transaction treated under section 356 instead, there would be no tax presently payable on either the stock or the bonds since no gain appears from the exchange of equivalent values.

\section{Rulings}

Following the release of these new regulations the Commissioner issued Revenue Ruling 56-541,72 in which he detailed his position with respect to a $D$ reorganization. The ruling involved a baseball

\footnotetext{
liquidation-reincorporation transaction. Nicholson, Recent Developments in the Reincorporation Area, 19 TAx L. REv. 123, 129 (1964). See Rice, When is a LiquidaNot a Liquidation for Federal Income Tax Purposes?, 8 STAN. L. REv. 208, 227 (1956) where he suggests that in the case of a reincorporation in which the only effect of the transaction is a "bail out" of surplus, the courts might be expected to hold that the property withdrawn from the continuing corporation was taxable under $\$ 301$. Thus the court might adopt an approach similar to Bazley (see note 23 supra) and hold that a distribution having the effect of a dividend should be taxed as such notwithstanding the fact that the transaction is cast in the form of a liquidation. See also Kuhn, Liquidation and Reincorporation Under the 1954 Code, 51 Geo. L.J. 96, 111 (1962).

oo INT. REv. CODE, § 356 (a) (2):

“(a) Gain on Exchanges.-

....

(2) Treatment as Dividend.-If an exchange is described in paragraph (1) but has the effect of the distribution of a dividend, then there shall be treated as a dividend to each distributee such an amount of the gain recognized under paragraph (1) as is not in excess of his ratable share of the undistributed earnings and profits .... The remainder, if any, of the gain recognized under paragraph (1) shall be treated as gain from the exchange of property."

${ }_{70}$ See generally Goldman, Revised "Reincorporation Doctrine" Upsets Planners: Rev. Rul. 61-156 Analyzed, $17 \mathrm{~J}$. TAXATION 148, 150 (1962).

71 See the example in Treas. Reg. $\$ 1.301-1(l)(1955)$.

${ }^{2}$ Rev. Rul. 541, 1956-2 Cum. Bull. 189, which was revoked by Rev. Rul. 156, 1961-2 Cum. BuLl. 62. Cf. Goldman, supra note 70, at 150.
} 
corporation's proposal to sell its assets to a new corporation and then liquidate. Approximately forty-five per cent of the new corporation's stock was to be held by shareholders of the old corporation. The Commissioner, approaching the question purely from the standpoint of a $D$ reorganization, ruled that the transaction was not a reorganization since the eighty per cent "control" requirement ${ }^{73}$ had not been met and it was therefore treated as a liquidating distribution entitled to capital gains treatment. This ruling was taken by some observers to indicate that a continuing interest in a new corporation of less than fifty per cent by old shareholders was not large enough to result in a denial of liquidation treatment. ${ }^{74}$ This im. pression of the Commissioner's attitude proved to be mistaken, however, for the baseball ruling was reversed in Revenue Ruling 61-156..$^{75}$ This new ruling asserted that where one corporation sold assets to a newly organized corporation and shareholders of the transferor owned forty-five per cent of the outstanding stock of the purchaser, the other fifty-five per cent having been underwritten to the public, a liquidation of the selling corporation is in substance a reorganization. ${ }^{76}$

Quite obviously this bold new position could not be validly based on a $D$ reorganization theory since the continuing interest was considerably below the eighty per cent precondition required by section 368 (c). ${ }^{77}$ In justifying the new ruling, emphasis was placed instead on the $E$ and $F$ reorganization provisions of section 368 (a) (1) which accord reorganization status to "recapitalizations," $(E),{ }^{78}$ and

${ }^{78}$ INT. REV. CODE OF 1954, $\$ 368$ (c).

“(c) Control. - . . the term 'control' means the ownership of stock possessing at least 80 percent of the total combined voting power of all classes of stock entitled to vote and at least 80 percent of the total number of shares of all other classes of stock of the corporation."

74 "The fact that the old shareholders acquired less than a majority interest led to speculation that the Service was thinking in terms of a 50 per cent control test ....." Nicholson, supra note 68, at 132.

${ }_{75}$ Rev. Rul. 156, 1961-2 Cum. BuL.L. 62, which revoked Rev. Rul. 541, 1956.2 CuM. BULL. 189.

${ }^{76}$ An adumbration of this change came when the Service announced a new procedural rule to the effect that there would be no rulings issued concerning gain by a corporation on sale of its assets incident to liquidation when more than a nominal amount of stock of both corporations was owned by the same persons. This new rule replaced a similar rule which had refused rulings where more than $50 \%$ of the stock of both corporations was in the ownership of the same persons. Rev. Proc. 6, 1960-1 Cum. Bull. 880, which was superceded by Rev. Proc. 32, 1962-2 Cum. Bull. 517, which was superceded by Rev. Proc. 31, 1964-2 Cum. BuLL. 947.

${ }^{77}$ See Kuhn, supra note 68 , at 96, 108.

${ }^{78}$ INT. REv. CODE of 1954, $\$ 368$ (a) (1) (E), see text quoted note 44 supra. 
to transactions which constitute "mere change in identity, form or [location] . .. " $(F) .{ }^{79}$ Unlike a $D$ reorganization, neither the $E$ nor the $F$ reorganization is subject to the section 368 (c) control requirements. ${ }^{80}$ Also avoided by use of the $E$ and $F$ reorganization route are the $D$ requirements that the transaction qualify under sections 354,355 , or $356 .^{81}$

In seeking to meet the tests of an $E$ reorganization the Commissioner drew upon the reasoning of his new regulations, ${ }^{82}$ arguing that "if the issuance of stock to the new investors is disregarded, there is clearly a mere recapitalization and reincorporation coupled with a withdrawal of funds."83 Seeking to forestall an argument that the issuance of stock to the new investors was an essential step in the overall transaction which would not be disregarded, 84 the ruling asserted that the public issuance was immaterial to the stockholders' "dominant purpose" of withdrawing corporate earnings. 85

The Commissioner's new approach was an attempt to deal with the situation where a liquidation was being used in connection with new financing and where the realities showed that those who controlled the old corporation would also control the new, even though their percentage interest in the new corporation would not mathematically assure them that control. However sound the Commissioner's arguments were when based on tax equity, his position was extremely weak when considered in the light of judicial precedent $^{88}$ statutory interpretation, ${ }^{87}$ and legislative history. ${ }^{88}$ Although the position of Revenue Ruling 61-156 has not been changed since

\footnotetext{
${ }^{70}$ INT. Rev. CODE of $1954, \$ 368$ (a) (1) (F), see text quoted note 44 supra.

${ }^{80}$ Goldman, supra note 70 , at 148 ; Morrison, supra note 64 , at $792-94$.

${ }^{81}$ See notes $37-40$ supra.

${ }^{82}$ See text accompanying notes 62-65 supra.

${ }^{83}$ Rev. Rul. 156, 1961-2 CuM. BuLl. 62, 63.

si See note 22 supra.

${ }^{85}$ Rev. Rul. 156, 1961-2 Cum. BuLl. 62, 63. See generally Goldman, supra note 70. Reliance was placed on Bazley v. Commissioner, 331 U.S. 737 (1947), and on legislative intention, H. CoNf. REP. No. 2543, 83d Cong., 2d Sess. 41 (1954).

${ }^{80}$ For a treatment of the cases arising and decided under the 1939 Code, see note 23 supra and accompanying text.

${ }^{87}$ See Morrison, supra note 64, at 797.

88 Provisions which would have had substantially the same effect as Rev, Rul. 61156 have failed twice to be enacted when proposed to Congress. See H. Conf. REP. No. 2543, 83d Cong., 2d Sess. 41 (1954); H.R. 4459, 86th Cong., lst Sess. \$ 26 (1959); cf. Rice, When is a Liquidation Not a Liquidation for Federal Income Tax Purposes?, 8 STAN. L. REv. 208, 225 (1956).
} 
its announcement $\mathrm{t}^{80}$ it has yet to receive judicial support ${ }^{00}$ and has been seriously questioned in recent Tax Court decisions. ${ }^{11}$

\section{Judicial Opinion}

The first case to consider the liquidation-reincorporation problem within the context of the 1954 Code revision was one tailor-made for a decision favorable to the Commissioner. ${ }^{92}$ In David $T$. $G r u b b s^{93}$ the Tax Court found a $D$ reorganization when the majority shareholder of Corporation A formed Corporation B. Corporation $B$ then acquired the assets of Corporation $A$ in exchange for cash which was then distributed to all shareholders of $\mathrm{A}$ except the majority shareholder in partial liquidation. Subsequently the former shareholders of $A$ purchased stock in $B$ in roughly the same proportion they had held in A. Applying the "step transaction" theory, the court held that the liquidation was merely one step in a reorganization and that the purpose of the transaction was to enable the shareholders to withdraw the earnings of the old corporation without terminating their interest in the business. ${ }^{94}$ Since one hundred per cent of the new corporation was owned by shareholders of the old corporation, even though there was a slight change in the ratio of ownership, the control requirements of Section 368 (c) were fully met. ${ }^{95}$

The Grubbs decision illustrates and reaffirms judicial willingness to thwart tax avoidance schemes where the evidence is clear that the eighty per cent control requirements have been satisfied.90 But the decision did little to resolve the more difficult case posed where

${ }^{\circ}$ See BNA, TAX MANAGEMENT 18-2ND PORTFolio on CoRPorate LIQUidations UNDER \$337, at 8 (Supp. 1965) [hereinafter cited as BNA Portrolro]. See also Pennell, Developments and Unanswered Questions in Corporate Reorganizations, 42 TAXEs 889, 898 (1964).

${ }^{00}$ See Nicholson, supra note 68, at 138. But see Pridemark, Inc. v. Commissioner, 345 F.2d 35 (4th Cir. 1965), reversing in part and affirming in part Pridemark, Inc., 42 T.C. 510 (1964); Lane, The Reincorporation Game: Have the Ground Rules Really Changed?, 77 HARv. L. REv. 1218, 1228 (1964).

os Reef Corp., P-H TAX CT. REP. \& MEM. DEc. (P.H Tax Ct. Mem.) \65,072 (March 31, 1965); Book Prod. Indus., Inc, P-H TAX CT. Rep. \& MEM. Dec. (P-H Tax Ct. Mem.) \65,065 (March 25, 1965); James C. Gallagher, 39 T.C. 144 (1962); cf. Note, 76 HARV. L. REv. 780, 805 (1963).

${ }^{82}$ Pennell, supra note 89 , at 899 .

9239 T.C. 42 (1962).

os Id. at 50.

${ }^{25} 39$ T.C. at 51. There is some intimation perhaps that a substantial change in the ratio of ownership might alone be sufficient. "The changes of percentages of ownership were not substantial and do not avoid the application of the reorganization statute." Ibid. (Emphasis added.)

${ }^{98}$ See note 25 supra and accompanying text. 
actual control is retained but formal control falls short of the eighty per cent required. Such a case arose in Joseph C. Gallagher, ${ }^{97}$ involving a Delaware corporation engaged in a stevedoring and terminal business. Shareholders of the corporation were of two distinct groupings; those engaged in active management and an inactive group comprised of estates and widows. A new corporation was organized by the active members for the purpose of precluding the inactive group from sharing in the profits of the business. The old corporation had at this time substantial undistributed earnings. A plan of liquidation was adopted under which the operating assets and active contracts were sold to the newly formed corporation. The old corporation then distributed the proceeds and its remaining assets to all of its shareholders. The old management group owned seventy-two per cent of the new corporation, the remainder being owned by officers and employees presently active in the business but who did not own any interest in the old corporation.

The Commissioner presented two alternative arguments to the Tax Court. ${ }^{88}$ It was first argued that because of the reincorporation there was no real substantive liquidation and therefore any distributions made during the course of the transaction were subject to treatment as dividends to the extent they represented earnings and profits of the corporation.99 But should the liquidation be considered complete, the Commissioner argued alternatively that the liquidation tax benefits should be denied because the liquidation was either a $D, E$ or $F$ reorganization. ${ }^{100}$

The Tax Court rejected the Commissioner's contention that no "real" liquidation took place. ${ }^{101}$ The court held that the liquidation here was not a "sham" and it could not be severed as a distinct transaction $^{102}$ so as to permit partial dividend treatment. ${ }^{103}$

\footnotetext{
${ }^{07} 39$ T.C. 144 (1962), 32 U. CiNa. L. REv. 416 (1963).

${ }^{08} 39$ T.C. at $155-56$.

Do See note 155 infra and accompanying text.

${ }^{100}$ See notes 36,44 supra.

10139 T.C. at 153. "The concept of a continuation of the . . business through a section 331 liquidation, coupled with an intercorporate transfer, falls into the general area of corporate reorganizations, so that it is in the so-called reorganization sections, if anywhere, that we should expect it to be dealt with." Ibid. The three dissenters in an opinion written by Judge Pierce disagreed: "Here, there was no actual or bona fide 'liquidation' of the incorporated business enterprise which had produced the accumulated earnings and profits. Actually, the business was never wound up or discontinued ...." 39 T.C. at 167 .

${ }^{102}$ Id. at 160 . See notes 45 supra and 151 infra.

${ }^{103}$ See note 66 supra and accompanying text.
} 
Having dismissed the Commissioner's attack on the substantiality of the liquidation, the court proceeded to consider whether the liquidation could be properly classified as a reorganization. ${ }^{104}$ The court first considered the $D$ reorganization and held that where the continuing shareholders owned only seventy-two per cent of the new corporation, the eighty per cent control requirement of section 368 (c) barred a $D$ classification. ${ }^{105}$ The court summarily rejected the $E$ and $F$ reorganization arguments underlying the Commissioner's Revenue Ruling 61-156,106 asserting that to find an $E$-type recapitalization-reorganization the facts must show a mere reshuffling of the capital structure within a single corporation. ${ }^{107}$ The Tax Court likewise rejected classification of the transaction as an $F$ type reorganization, holding that on the facts this was hardly a mere change of identity. ${ }^{108}$

There were three dissents in Gallagher, all of which concentrated on the Commissioner's first argument, based on lack of a complete liquidation. None of the dissenters quarrelled with the court's rejection of the Commissioner's $E$ and $F$ reorganization arguments. ${ }^{100}$

10439 T.C. at 161-62.

${ }^{205}$ Id. at 161. In view of the reluctance of the Commissioner to give up his position in Rev. Rul. 61-156, see note 89 supra, there has been speculation that the amount of continuing "control" he considers an invitation to attack is any amount over 20\%. BNA TAX Management, Memo. 64-22, at 11 (Oct. 26, 1964), qualifies its position by adding the requirement that the $20 \%$ ownership must be supported by a bona fide business purpose. See Nicholson, supra note 68, at 139.

${ }^{108}$ Note 75 supra; see BNA PORTFOLIo 7; Lane, supra note 90, at 1256; Morrison, supra note 64, at 792; Nicholson, supra note 68, at 138.

10739 T.C. at 162. See Helvering v. Southwest Consol. Corp., 315 U.S. 194, 202-08 (1936), relied on by the Tax Court in Gallagher, where the Supreme Court held "there was not that reshuffling of a capital structure, within the framework of an existing corporation, contemplated by the term "recapitalization." Id. at 202. (Em. phasis added.)

10839 T.C. at 162.

108 The cases under the recapitalization provision $E$ have followed the Supreme Court's lead in limiting its application to alterations within a single corporation. Morrison, supra note 64, at 793; cf. Nicholson, supra note 68, at $133 \mathrm{n} .31$, and accompanying text. As for the $F$ reorganzation it has generally been thought limited in application to cases of change of corporate domicile or state of incorporation. Sce Ahles Realty Corp. v. Commissioner, 71 F.2d 150 (2d Cir. 1934), cert. denied, 293 U.S. 611 (1934); George Whittel \& Co., 34 B.T.A. 1070 (1936); Nicholson, supra note 68, at 134 (limited to change of domicile). Paul stated in 1940 that the type $F$ reorganization (unchanged in form since then) "is so little relied upon by taxpayers that this part of the statute has indeed perished through lack of use." Paul, Studies IN FEDERAL TAXATION 82 (3d ser. 1940). Bittker has suggested, however, that it may "come to play an increasingly important role." BitTKer, FEdERAL Income Taxation OF CORPORATIONS AND SHAREHOLDERS 383 (1959). In an excellent survey article of the 1954 changes in the Code, Cohen, Silverman, Surrey, Tarleau \& Warren, The Internal Revenue Code of 1954: Corporate Distributions, Organizations and Reorganizations, 
There is considerable support for the court's interpretation of the $E$ and $F$ reorganization sections in Gallagher. ${ }^{110}$ Thus, while there may be reason to suspect that the court in Gallagher was influenced by the "substantial business reasons" 111 for the transaction existing aside from tax considerations, ${ }^{112}$ there is little evidence that the case will be easily distinguished in future situations where less than the statutory control is present. ${ }^{113}$

\section{RECENT DEVELOPMENTS}

Cases subsequent to Gallagher have indicated only a reluctant willingness on the part of some courts to devise alternative approaches to a $D$ reorganization so as to avoid the eighty per cent control requirement. Many decisions have steadfastly adhered to the Gallagher determination.114 Other cases have, however, revealed that the courts will strain to negate non-control prerequisites to a reorganization when the required control is present. ${ }^{115}$

A recent decision illustrating judicial acquiescence in new methods of achieving a reorganization result by other than the $D$

68 HARv. L. REv. 393, 420 (1955), it was stated with reference to the $F$ reorganization, "This provision has always been rather obscure, and its re-enactment furnishes no clarification as to its content." See also Lane, supra note 90, at 1247. But see SURREY \&. Warren, Federal Income Taxation 1525, 2588 (1960 ed.).

${ }^{110}$ See Lane, supra note 90, at 1243-44; Mayer, Ramifications of the Treasury's Liquidation-Reincorporation Doctrine, 25 U. PITT. L. REv. 637, 650-51 (1964); Morrison, supra note 64, at 797; Nicholson, supra note 68, at 134-38; Pennell, supra note 89, at 898-99. The three dissenters in Gallagher did not quarrel wtih the Tax Court's rejection of the Commissioner's $E$ and $F$ arguments. Rather, they were of the opinion that there had not been a complete liquidation in substance. 39 T.C. at 16468 (dissenting opinion).

11 These "substantial business reasons" included: (1) eliminating inactive estates and widows who held $38 \%$ of the stock in the corporation which thereby prevented a minority $20 \%$ shareholder from acquiring control by influence exerted on the inactive shareholders; (2) allowing eight executives of the business to become shareholders. 39 T.C. at $146-48$.

112 Nicholson, supra note 68, at 143-44; Pennell, supra note 89, at 898 .

${ }^{113}$ See Morrison, The Line Between Liquidations and Reorganizations, 41 TAxEs 785 (1963). But see Pennell, supra note 89, at 898, where he expresses the feeling that Rev, Rul. 61-156 is making headway despite Gallagher.

114 See Pridemark, Inc. v. Commissioner, 345 F.2d 35 (4th Cir. 1965), affirming in part and reversing in part, 42 T.C. 510 (1964); Reef Corp., P.H TAX CT. REP. \& MEM. Dec. (P-H Tax Ct. Mem.) \& 65,072 (March 31, 1965); Book Prod. Indus., Inc., P-H TAX CT. ReP. \& Mem. Dec. (P.H Tax Ct. Mem.) 165,065 (March 25, 1965); Hyman H. Berghash, 43 T.C. 743 (1965).

${ }^{115}$ See Commissioner v. Morgan, 288 F.2d 676 (3d Cir. 1960) (exchange); Book Prod. Indus., lnc., supra note 114 (substantially alI); South Texas Rice Warehouse Co., 43 T.C. 540 (1965) (exchange and substantially all); James Armour, Inc., 43 T.C. 295 (1965) (exchange and substantially all); Roy G. Anderson, 33 P-H Tax C. Mem. 647 (1964) (substantially all); John G. Moffatt, 42 T.C. 558 (1964) (substantially all). 
reorganization conduit is Pridemark, ${ }^{110}$ a decision authored by a Gallagher dissenter. ${ }^{117}$ In Pridemark, assets of a liquidating company were distributed in kind to shareholders who immediately assigned them to a trustee. Within a short time, the trustee acquired one hundred per cent of the stock of a new corporation in exchange for part of the assets of the liquidated corporation, whose shareholders were then given stock in the new corporation by the trustee. ${ }^{118}$ The Tax Court held, alternatively, that there was no complete liquidation both because there was no "true intention to wind up the business" and that on these facts there was a "mere change of identity"'119 resulting in an $F$ reorganization. ${ }^{120}$

$\mathrm{No}$ cases were cited and no legal analysis was given for the court's $F$ reorganization holding. Furthermore, no attempt was made to distinguish the Gallagher decision, which rejected an $F$ reorganization contention. ${ }^{121}$ While Pridemark is distinguishable from Gallagher on the ground that the statutory control requirements absent in Gallagher were present in Pridemarh, ${ }^{122}$ the court's finding that the transaction constituted an $F$ reorganization is subject to question.

Considering the Pridemark case on appeal, the Court of Appeals for the Fourth Circuit reversed the decision in a recent opinion. ${ }^{123}$ While the Court of Appeals disapproved the tax court's $F$ reorganization theory ${ }^{124}$ its decision should not be read as a complete victory for future taxpayers. Referring to the Conference Report purport-

\footnotetext{
${ }^{118} 42$ T.C. 510 (1964), aff'd in part, rev'd in part, 345 F.2d 35 (4th Cir. 1965).

${ }_{117}$ Pierce, $J$. See note 131 infra.

${ }^{118}$ The Court of Appeals viewed the liquidation as a "genuine" desire to get out of the business with a subsequent change of mind, after disappointment in new ventures, and return to the old "business" but with new opcrating assets (agreements and salesmen primarily) and in competition with the previously sold business. $345 \mathrm{~F} .2 \mathrm{~d}$ at 42. See text accompanying note 123 infra.

xxo 42 T.C. at 532.

${ }^{120}$ In Gallagher only $72 \%$ of the stock of the new corporation was held by old shareholders, see note 105 supra and accompanying text. In Pridemark $100 \%$ of the stock of the new corporation was held by old shareholders. 42 T.C. at 522.

Prior to Pridemark, the $F$ reorganization provision had been considered unimportant in dealing with reorganizations. See BITTKER, op. cit. supra note 109, at 883 . 12139 T.C. at 117.

$122 \mathrm{Cf}$. note 105 supra and accompanying text.

${ }^{123} 345$ F.2d 35 (4th Cir. 1965).

124 The Court of Appeals quoted Lane, supra note 90, and stated that the $F$ reorganization has generally been used only where "the transferec [is] no more than the alter ego of the transferor." $345 \mathrm{~F} .2 \mathrm{~d}$ at 42 . The court did, however, recognize that the $F$ type reorganization has recently received increased judicial attention in broader contexts. Ibid. See note 120 supra.
} 
ing to authorize some judicial maneuvering in this area, the court merely held that the facts of this case fail to "bring it within the reincorporation area because the transactions were not motivated by a desire to avoid the payment of taxes." 125 Furthermore the court did not reject out of hand as had the Gallagher court the view that a "complete liquidation" is required to avoid reorganization treatment. ${ }^{126}$ The court's test for a complete liquidation was whether or not the liquidated business was "resumed by the corporation as a continuation of a going concern ...."127 Mere compliance with state liquidation laws is not enough;128 there must in fact be a complete liquidation. Such a position would appear to be directly contrary to the Gallagher decision, which denied the existence of any special factual meaning inherent in the phrase "complete liquidation." 129

While cases such as Pridemark point the way to a solution outside the $D$ reorganization, other cases working within subsection $D$ have sought to deal with the non-control reservations imposed there and have made significant inroads on their restrictiveness. In this regard one pair of cases ${ }^{130}$ is particularly illustrative. ${ }^{131}$ In James Armour, Inc., ${ }^{132}$ the taxpayers owned two separate corporations, one of which rented equipment to the other for use in heavy construction work. For what were determined to be valid business as well as tax reasons, it was decided to liquidate the rental corporation after sale of its assets to the construction company. All of the operating assets were sold to the construction company except for an office building, title to which was distributed to the rental corporation's shareholders and then leased to the construction company. Also included in the liquidating distribution was a considerable monetary sum representing undistributed profits and earnings. The Tax Court

\footnotetext{
${ }^{226} 345 \mathrm{~F} .2 \mathrm{~d}$ at 41 . (Emphasis added.)

${ }^{220} I d$. at $40-41$. This would seem to be renewal of the "continuing interest" doctrine discussed in note 46 supra.

$127345 \mathrm{~F} .2 \mathrm{~d}$ at $4 \mathrm{I}$.

128 Ibid.

${ }^{120}$ See note 101 supra and accompanying text.

${ }^{130}$ Pridemark, Inc., 42 T.C. 510 (1964), aff'd in part, rev'd in part, 345 F.2d 35 (4th Cir. 1965); James Armour, Inc., 43 T.C. 295 (1964).

${ }^{282}$ It should be kept in mind that both opinions were written by dissenters in the Gallagher decision. The dissenting judges in Gallagher were Judges Pierce (opinion), Raum, and Atkins. Atkins wrote the opinion in Armour and Raum authored Moffat. ${ }^{282} 43$ T.C. 295 (1964).
} 
denied the taxpayers capital gains treatment with respect to the "boot" received and held them taxable under section 356 to the extent of their gain. ${ }^{133}$ The court also denied the construction company a depreciation deduction based on a step-up in basis on the assets which were purchased from the liquidated company. ${ }^{134}$

The taxpayer in Armour unsuccesfully asserted two defenses. It was argued first there was no $D$ reorganization because the transaction did not embody one requisite of such a reorganization, a finding under section 354 that "substantially all" of the assets of the liquidating corporation were transferred to the new corporation. ${ }^{135}$ It was contended that the retention and distribution to shareholders of substantial cash and an office building precluded such a finding. The only previous interpretation of the "substantially all" requirement as added to the definition of a $D$ reorganization by the 1954 amendments was in John G. Moffatt. ${ }^{138}$ In that case it was held that the retention of a few minor items, including land no longer of any import to the corporate business, did not prevent a finding that substantially all of the corporate assets had been transferred. ${ }^{137}$ Armour extended this interpretation by holding, in reliance on Moffatt, that where the purchasing company acquires title to or use of the assets essential to the operation of the old business enterprise there has been a transfer of "substantially all" of the assets wtihin the meaning of section 354.138

It was also argued before the Armour court that a reorganization was precluded because the technical requirement of an "exchange and distribution of stock" provided for under section $354^{130}$ was not met. No stock of the purchasing company had been issued and a fair market value was paid for the assets. The court, however, construed the exchange provisions as requiring only that when the series of transactions has been completed, stockholders of the old corporation must have retained their "proprietary interests in the

\footnotetext{
${ }^{183} \mathrm{Id}$. at 310 .

184 Id. at 313.

${ }^{285}$ See note 37 supra; cf. Holzman, Corporate Reorganizations $\$ 3: 7$ (2d ed. 1955). 18042 T.C. 558 (1964).

${ }^{137}$ Id. at 423. See Roy G. Anderson, 33 P-H Tax Ct. Mem. 647. "The fact that substantially all of the assets ... were not transferred ... prevents the transaction from qualifying as either a subsection $C$ or $D$ reorganization." Id. at 653 . See also James Armour, Inc., 43 T.C. 295, 308 (1964); Edward H. Russell, 40 T.C. 810, 823 (1963), aff'd, 345 F.2d 534 (5th Cir. 1965).

13843 T.C. at 309.

${ }^{189}$ See note 37 supra; cf. note 36 supra; HoLzMaN, op. cit. supra note 135 , at $\$ 3: 5$.
} 
same going business."140 Support for this construction was drawn from reorganization cases construing similar "exchange" requirements under the 1939 Code $^{141}$ and holding that no new issuance of stock was required when it would have been only a "meaningless gesture."142 While it is true that under the 1939 Code "exchange" was not an integral part of the definition of a $D$ reorganization as it is under the 1954 Code, since it can be assumed that Congress was aware of the construction of the word "exchange" this distinction does not appear to be crucial. Further, in view of the Congressional exhortation to the judiciary to utilize interpretative powers to frustrate tax avoidance $\mathrm{e}^{\mathbf{1 4 3}}$ it would seem a permissible interpretation of the intended coverage of the reorganization sections. ${ }^{144}$

Armour and Moffatt together indicate a willingness on the part of the Tax Court to construe narrowly the limitations added by the 1954 Code to the definition of a $D$ reorganization. ${ }^{145}$ Both decisions further indicate the Tax Court's predisposition to expand the scope of the reorganization sections where the language is accordingly susceptible. ${ }^{148}$ The explicit requirement of continuing control, however, still poses a pitfall. With the expansive interpretations given other limitations, the element of control is the one significant roadblock in the path of effective elimination of abuse in liquidations by use of the $D$ reorganization. ${ }^{147}$

An example of the reluctance of the courts to disregard the statutory control requirement is the recent decision of Hyman Berghash, ${ }^{148}$ where the Tax Court reaffirmed its Gallagher position in a situation where less than eighty per cent control was present. ${ }^{149}$

\footnotetext{
26043 T.C. at 308.

141 INT. REv. CODE OF 1939, §112 (b) and (c) (2).

142 Commissioner v. Morgan, 288 F.2d 676 (3d Cir. 1961). "That an existing corporation in which the taxpayer was the sole shareholder was used instead of a newly formed one cannot alter the true nature of the transaction. Here the issuance of new stock would have been a meaningless gesture ...." Id. at 680 .

${ }^{148}$ See note 31 supra.

1"4 See Lane, The Reincorporation Game: Have the Ground Rules Really Changed?, 77 Harv. L. REv. 1218, 1232 (1964). But see Pennell, Developments and Unanswered Questions in Corporate Reorganizations, 42 TAXEs 889, 897 (1964).

${ }^{145}$ But see note 131 supra; cf. Pennell, supra note 144, at 899-901.

${ }^{140}$ Cf. Holzman, op. cit. supra note 135 , at $\$ 3: 5,3: 7$.

${ }^{117}$ See Mayer, supra note 110, at 647-50; Nicholson, Recent Developments in the Reincorporation Area, 19 TAx L. REv. 123, 138-39 (1964); Pennell, supra note 144, at 898-99.

14843 T.C. 743 (1965).

${ }^{160} I d$. at 756.
} 
Berghash and his wife owned one hundred per cent of the stock of a corporation which operated a single drugstore. Wishing to expand his operations, Berghash hired Lettman as his general manager with a view to developing another drugstore owned fifty per cent by Berghash and fifty per cent by Lettman. When this expansion did not materialize, Berghash agreed to tender a fifty per cent share in the existing corporation to Lettman. Lettman lacked funds to purchase a fifty per cent interest, and it was decided that to consummate this transaction he would purchase for cash onehalf the outstanding stock of a dormant corporation owned by Berghash and Lettman. Berghash's operating corporation then sold its operating assets to the dormant corporation in exchange for the cash received from Lettman's stock purchase, fifty per cent of the unissued stock and the balance in promissory notes. In this manner, considerable accumulated profits of the operating corporation were distributed to Berghash, and Lettman was able to finance the transaction partially by indebtedness. The Commissioner presented four theories in seeking to prevent liquidation treatment but all were rebuffed.150 (l) He claimed that the transaction was a mere sham, to which the court replied that it appeared bona fide in every respect and that any scheme to minimize the tax burden was incidental to the dominant purpose of financing the purchase. ${ }^{161}$ (2) The Commissioner then argued that the Tax Court's decision in Pridemark applied and that the transaction was an $F$ reorganization. ${ }^{152}$ In distinguishing Pridemark, the court held to be crucial the "drastic shift in the proprietary interests." 153 (3) The Commissioner's third approach was posited on a $D$ reorganization argument. Citing Gallagher and refusing to consider each step in the trans-

$1501 d$. at 748-59.

${ }^{151}$ While reciting Knetsch v. United States, 364 U.S. 361 (1960) and Higgins v. Smith, 308 U.S. 473 (1940) in support of the generally recognized doctrine that sham transactions will be disregarded, the Berghash court refused to impute a "sham" to the transactions before it merely because a genuine transaction (one amply supported by business reasons and possessed of economic substance) was carried out in a manner achieving maximum tax advantage. 43 T.C. at 749.

${ }^{182}$ This was prior to the decision on appeal of Pridemark. See note 123 supra and accompanying and following text.

${ }^{153} 43$ T.C. at 754. The court reaffirmed the rule that where there is a change in stock ownership, the transaction fails to qualify as an $F$ reorganization. Cf. Joseph C. Gallagher, 39 T.C. 144 (1962); Stollberg Hardware Co., 46 B.T.A. 788 (1942); Cushman Motor Works v. Commissioner, 130 F.2d 977 (8th Cir. 1942), affirming 44 B.T.A. 1288 (1941). 
action separately, ${ }^{154}$ the court found the requisite eighty per cent continuing control absent. (4) Finally, it was contended that no complete liquidation had taken place. Again citing Gallagher, the court refused to look beyond the prima facie "actual liquidation and dissolution." 155 Berghash therefore closely follows the Gallagher decision. Its only deviation is its refusal to reject the lower court decision in Pridemark. Instead, the radical shift in proprietary interest was found to be too great to allow an $F$ reorganization. This leaves open the question of whether there is some point between fifty and eighty per cent control where the court will deem such a transaction a reorganization.

Yet another case strictly adhering to the eighty per cent control requirement ${ }^{158}$ is Book Prod. Indus., Inc., ${ }^{157}$ which involved an extremely sizable alleged deficiency, more than two million dollars arising from the sale of stock distributed in the liquidation of a close corporation, Middle States, which had previously owned both that stock and sizable holdings of real estate. On liquidation, certain real estate which was desirable for a shopping center was sold by Middle States to a new corporation owned by the wife of its principal shareholder. Promissory notes and some cash were received in exchange for the realty and distributed to the shareholders of Middle States.

The Commissioner contended that the new entity was merely a continuing enterprise and that the promissory notes given in exchange for the property represented, in the hands of former Middle States shareholders, an equity interest in the new corporation sufficient to meet the control requirements of section 368 (c) and hence brought the entire transaction under the reorganization provisions of the Code. The court, however, rejected these contentions. ${ }^{158}$ With respect to the assertion that the corporation was a continuing enterprise, thus making the transaction an $F$ reorganization, the court distinguished Pridemark (Tax Court decision) on the ground that less than one-half of the value of the old corpora-

\footnotetext{
154 43 T.C. at 756. See note 22 supra for discussion of the Step Transaction.

${ }^{155} 43$ T.C. at 759. See note 101 supra. But see note 127 supra and accompanying text.

${ }^{160}$ See also Reef Corp., P-H TAX CT. REP. \& MEM. Dec. (P-H Tax Ct. Mem.) \65,072 (March 31, 1965).

${ }^{107}$ P.H TAX CT. Rep. \& Mem. Dec. (P-H Tax Ct. Mem.) f 65,065 (March 25, 1965).

168 Id. at 386 .
} 
tion's only operating assets, the realty, was transferred to the new corporation, all of whose stock was held by new shareholders. ${ }^{100}$

With respect to the contention that equity holdings may be used in computing continuing control, the court recited as a wellestablished rule in the reorganization area that a debt cannot be equated with a proprietary interest. Gallagher was invoked as authority for the conclusion that, even accepting the equity argument, only seventy-two per cent of the transferee would be controlled by old shareholders of the transferor, a percentage insufficient to meet the control requirements of section 368 (c). ${ }^{180}$ Thus, the rigid eighty per cent rule remains viable and has withstood all attempted erosions.

\section{ConcLusion}

Congressional inaction ${ }^{161}$ has necessitated imaginative adaptation of the reorganization sections of the Code to curb abuses of the liquidation tax preference. Even with such improvisation, in many respects the reoganization provisions have not proved equal to the task. Among the impediments to effective utilization of the reorganization sections, the most troublesome is the problem of control. The single-percentage system and the unsynchronized dual objectives which the reorganization sections are intended to achieve work at cross-purposes. A high percentage of control is necessary to curb avoidance in the sale-reorganization context and a low percentage is requisite to avert abuse of the liquidation preference. ${ }^{102}$ The best that can be hoped for within the single-percentage system is the setting of a percentage which will prevent the grossest and most flagrant abuses in both areas. There is ample indication that the present eighty per cent rate, while effective in preventing sales from masquerading as reorganizations, is of limited effectiveness in curbing reorganizations masquerading as liquidations. ${ }^{103}$

A realistic appraisal of the situation makes it apparent that while

${ }^{159}$ Id. at 388 .

This case points up the absence of an attribution requirement in the reorganization area and the potential abuses which may result by transfers from hushands to wives or among other related persons. Cf. INT. REV. CoDE of 1954, $\$ \S 267,318$.

${ }^{100}$ For a discussion of Book Prod. Indus., Inc. prior to actual decision see Pennell, stupra note 144 , at 901-02.

${ }^{102}$ See notes 26, 31 supra.

${ }^{102}$ See text accompanying notes 56-59 supra.

${ }^{203}$ See cases cited note 114 supra. 
legislative action ${ }^{164}$ is the surest cure for the evils arising from misuse of the liquidation preference, the proposals which would have effected such a cure have been repeatedly rejected. ${ }^{165}$ Perhaps the Gallagher, Pridemark and Berghash decisions, all of which have been decided subsequent to the last attempted legislative reform, ${ }^{166}$ will be enough to convince Congress that the answer lies in a revision of the Code and not in ad hoc development in the courts. The remedies, for the present, however, appear to lie within the existing framework of the Code and the extent to which the Commissioner can manipulate and marshal its provisions. ${ }^{167}$

The judicial response to the Commissioner's current endeavors has been at best mixed. While the Gallagher decision indicates the unwillingness of the courts to circumvent the requirement of control, Armour and Moffatt indicate that the court is at least willing to either brush the restrictions aside or gloss their impact in an attempt to curb abuse.

The recent decisions in Pridemark (Fourth Circuit) and Berghash (Tax Court), while resulting in current taxpayer victories, are perhaps the most promising harbingers of future reorganization treatment for reincorporations whose primary objective is a tax advantage unaccompanied by any substantial business purpose. These cases offer a fertile field from which new doctrine may grow when abuse proves flagrant.

$$
\text { r.h.s. }
$$

\footnotetext{
${ }^{106}$ Legislative revision could mitigate the ineffectiveness of the reorganization sections either by removing the benefits of $\$ 331$, limiting the liquidation preferences, altering the percentage control requirement, or devising new approaches.

${ }^{105}$ See note 31 supra.

${ }^{100}$ See note 31 supra.

${ }^{287}$ See authorities cited note 35 supra.
} 